\title{
Comparison of nursing workload in a Pediatric Intensive Care Unit estimated by three instruments
}

\author{
Comparação da carga de trabalho de enfermagem em Unidade de \\ Terapia Intensiva Pediátrica estimada por três instrumentos \\ Comparación de la carga de trabajo de enfermería en Unidad de \\ Cuidados Intensivos Pediátrica estimada por tres instrumentos
}

How to cite this article:

Velozo KDS, Costa CAD, Tonial CT, Crestani F, Andrades GRH, Garcia PCR. Comparison of nursing workload in a Pediatric Intensive Care Unit estimated by three instruments. Rev Esc Enferm USP. 2021;55:e00547. DOI: https://doi.org/10.1590/1980-220X-REEUSP-2020-0547

Kelly Dayane Stochero Velozo ${ }^{1}$

Caroline Abud Drumond Costa ${ }^{2}$

Cristian Tedesco Tonial ${ }^{3}$

Francielly Crestani ${ }^{3}$

Gabriela Rupp Hanzen Andrades ${ }^{3}$

Pedro Celiny Ramos Garcia ${ }^{4}$

${ }^{1}$ Universidade Federal do Pampa, Uruguaiana, RS, Brazil.

${ }^{2}$ Hospital Moinhos de Vento, Pós-Graduação em Nutrição Materno Infantil, Porto Alegre, RS, Brazil.

${ }^{3}$ Pontifícia Universidade Católica de Porto Alegre, Porto Alegre, RS, Brazil.

${ }^{4}$ Pontifícia Universidade Católica de Porto Alegre, Escola de Medicina, Departamento de

Pediatria, Porto Alegre, RS, Brazil.

\section{ABSTRACT}

Objective: To compare the nursing workload using the Nursing Activities Score (NAS), Therapeutic Intervention Scoring System-28 (TISS-28) and Nine Equivalents of Nursing Manpower Use Score (NEMS) instruments in children admitted to a Pediatric Intensive Care Unit in a university hospital. Method: A prospective cohort study performed in a Pediatric Intensive Care Unit, with a sample formed of all children hospitalized during the study period. Nursing workload was evaluated using the TISS-28, NEMS and NAS instruments, and further divided into two groups: Group 1 forming a category of basic activities items and Group 2 forming a category of other support and intervention activities. Results: The sample consisted of 490 Pediatric Intensive Care Unit admissions, totaling 4617 observations. NAS presented the best estimate of total working hours. TISS-28 and NEMS showed better agreement and the results showed strong correlations between NAS and TISS-28 and between NEMS and TISS-28. In Group 1 (basic activities), NAS(1) and TISS-28(1) showed moderate correlation, in Group 2 (specialized activities) the three instruments showed strong correlations. Conclusion: NAS stood out in the evaluation of nursing workload and showed good correlation and agreement with the TISS-28.

\section{DESCRIPTORS}

Pediatric Nursing; Workload; Intensive Care Units, Pediatric; Nursing, Team. 


\section{INTRODUCTION}

Pediatric Intensive Care Units (PICUs) are intended for children hospitalized with potentially serious illnesses and compromised physiological systems, who require intensive support and treatment, and specialized continuous professional care. The nursing role within the PICU is important for the care of critically ill children and an adequately sized nursing team is fundamental for the safety and quality of care provided ${ }^{(1)}$.

Instruments used to evaluate nursing workload can contribute to the measurement and planning of nursing staff numbers and appropriate provision of human resources in these intensive care units. Tools have been developed in recent decades aimed at more objectively estimating the nursing workload. Among them is the Therapeutic Intervention Scoring System-28 (TISS-28) ${ }^{(2)}$ and two other instruments derived from it, the Nine Equivalents of Nursing Manpower Use Score (NEMS) ${ }^{(3)}$ and Nursing Activities Score (NAS) ${ }^{(4)}$. The instruments TISS-28 and NEMS measure the patients' therapeutic needs and relate them to the severity of their condition, while in addition to these measurements, the instrument NAS assesses the care activities performed, regardless of severity ${ }^{(5-6)}$. These three instruments can be used to estimate nursing workload. The items making up these indicators can be grouped into seven categories, corresponding to basic activities, ventilator, cardiovascular, renal, neurologic and metabolic support, and specific interventions.

Nursing workload is linked to those activities performed directly or indirectly with the patient and includes education activities and administrative and managerial tasks performed by nurses ${ }^{(7)}$. In a systematic review, focusing on adult inpatient units, an extensive variety of tools to assess the nursing workload was identified ${ }^{(8)}$. The use of scores to measure nursing workload in the ICU for adults has been widespread in recent years, and in another systematic review on the subject NAS showed the best performance ${ }^{(9)}$. As described above, the focus of current research has been the assessment of instruments to measure nursing workload in an adult intensive care setting ${ }^{(10-12)}$ and few studies have been conducted in pediatric intensive care units ${ }^{(13-14)}$.

The aim of this study was to compare the nursing workload using the instruments NAS, TISS-28 and NEMS in children admitted to a pediatric ICU of a tertiary university hospital; and based on this comparison, to verify if there is any advantage of using one instrument over another.

\section{METHOD}

\section{Study Design}

Analysis of the database of a prospective observational cohort study was conducted in a PICU of a philanthropic university hospital, between June 1, 2011 and June 31, 2012.

\section{Population}

All children and adolescents admitted to the PICU during the study period were included in the study. Any patient readmitted to the unit after having been discharged was considered a new participant.

\section{Data Collection}

Patients' clinical and demographic data were collected, including: reason for hospitalization, length of hospital stay, origin of patient (hospital unit, surgical center, emergency room, and transfer from another hospital), outcome, body system dysfunction (respiratory, neurologic, cardiovascular, gastrointestinal, hematologic, renal and hepatic), age, and sex.

Nursing workload was evaluated by application of the instruments TISS-28, NEMS and NAS. TISS-28 consists of seven major categories: basic activities, ventilator, cardiovascular, renal, neurological and metabolic support, and specific interventions. Each of these categories are further broken down into more focused areas, resulting in the total of 28 items evaluated by the instrument ${ }^{(2,15-16)}$. NEMS consists of just nine items, which have been extracted from TISS-28 $8^{(3,17)}$. NAS consists of the same seven major categories of TISS-28, but items have been rearranged and aspects related to hygiene, patient mobilization and positioning, patient and family member support and care, and administrative and management tasks have been included in the basic activities category, bringing the total of evaluated activities to $23^{(4,6)}$.

The attending nurse responsible for the patient recorded, at the end of each work shift, the details of those items on NAS that consumed time and/or quantity of staff. Data required for calculation of the instruments and other items forming these tools were collected daily by the researcher, using the medical and nursing records referring to the previous 24 hours of hospitalization, taken from individual patient records. Children were followed-up during the entire duration of their hospitalization in the PICU, with each day being considered one observation period.

\section{Data Analysis and Processing}

The name of the tools used in this study, NAS, TISS-28 and NEMS, were maintained for the total instrument score. These indicators were also further stratified into two groups, with Group 1 comprising items classified as basic activities and Group 2 other activities involving ventilator, cardiovascular, renal, neurological and metabolic support, and specific interventions. This way, Group 1 of NAS included the items of monitoring and control, hygiene procedures, patient mobilization and positioning, patient and family member support and care, administrative and management tasks, laboratory investigations, medications and caring for drains; all these items were grouped and labeled NAS(1), and the remaining items were also grouped and called NAS(2). TISS-28 items of monitoring and control, laboratory investigations, single medication and multiple intravenous medication administration, caring for drains, and routine and frequent dressing changes were grouped together and labeled TISS-28(1), and the remaining items were also grouped and called TISS-28(2). NEMS Group 1, 
defined as NEMS(1), included the items of monitoring, control and medications, and the remaining items were grouped and labeled NEMS(2).

For the purpose of analysis and presentation of the results and to ensure that all instruments had a similar unit for comparison, NAS, TISS-28 and NEMS scores, together with those in Groups 1 and 2, were converted to nursing working hours for the 24-hour assistance period. For this conversion, the daily sums of TISS-28 and NEMS scores were multiplied by 3 and $10.6 \mathrm{~min}^{(18)}$, and the sum of NAS was multiplied by 14.4 minutes $^{(19)}$ and the values obtained were then divided by 60 . This calculation result refers to the nursing workload, signifying the mean time of assistance in hours that each patient required in a 24-hour period.

Descriptive statistics was applied for data analysis. Categorical variables were presented as percentages and continuous variables as mean and standard deviation. Analysis of variance (ANOVA) was performed, followed by Tukey's post-hoc test for comparison of pairs among ANOVA variables. The association among the instruments was calculated using Pearson's correlation coefficient and simple linear regression. The Bland-Altman model ${ }^{(20)}$ and graphic analysis were used to verify agreement among the scores. The results were considered statistically significant if $\mathrm{p}<0.05$, with a $95 \%$ confidence interval, and a statistical significance level $(\alpha)$ of $5 \%$, with power $(1-\beta)$ of $80 \%$. Data analysis was conducted using the software Statistical Package for the Social Sciences (SPSS ${ }^{\circledR}$ ), version 17.0 .

\section{Ethical Aspects}

The study was approved by the institutional Research Ethics Committee under number 11/05482, with no need for a completed Informed Consent Form.

\section{RESULTS}

The sample consisted of 490 PICU admissions. Each day the subject remained hospitalized was considered as an observation, totaling 4617 observations of NAS, TISS-28 and NEMS scores during the study period. Of the children who formed the sample, 260 (53\%) were male, 189 (39\%) younger than 1 year, 136 (28\%) aged between 1-5 years, and $56(11 \%)$ aged more than 12 years. In relation to the origin of these children, 214 (44\%) were admitted to the PICU from the surgical center, 103 (21\%) from the emergency room, 97 (20\%) from a hospital ward, and 76 (16\%) from another hospital. Many children presented more than one body system disturbance during hospitalization, with 300 (61\%) presenting a respiratory dysfunction; 156 (32\%) neurologic; 125 (26\%) cardiovascular; 117 (24\%) gastrointestinal; 104 (21\%) hematologic; 88 (18\%) renal; and 23 (5\%) hepatic dysfunctions. In addition, 43 (9\%) of the children presented no organ dysfunction.

Table 1 presents the mean scores for admissions, maximum scores recorded on instruments NAS, TISS-28 and NEMS, and estimates of the mean number of nursing work hours in the 24-hour period. NAS, TISS-28 and NEMS Means refer to data from the 4617 observations. NAS, TISS-28 and NEMS Admission and Maximum relate to data from the 490 patients on the day of admission to the PICU and the day with the highest score, respectively.

Table 2 presents the mean work hours in Groups 1 and 2, and the total mean hours of instruments NAS, TISS-28 and NEMS. In Group 1, NAS score assessed the nursing workload more accurately in the basic activities category when compared to the other scores. In group 2, the best score for measuring working hours in the other categories of supports and therapeutic interventions was TISS-28. Overall, by evaluating the total average hours of the scores, NAS showed a better measure of the general nursing workload in the 24 hours of care.

The correlation of average working hours estimated by instruments NAS, TISS-28 and NEMS and stratification in Groups 1 and 2 is shown in Table 3. Both NAS and TISS-28, NEMS and TISS-28 scores show a strong correlation. In Group 1 stratification analysis, only NAS(1) and TISS-28(1) showed moderate correlation and other data were poorly correlated. In Group 2, strong correlations were found between the average working hours.

Table 1 - Scores for the instruments NAS, TISS-28 and NEMS, and estimation of nursing work hours - Porto Alegre, RS, Brazil, from June 2011 to June 2012.

\begin{tabular}{|c|c|c|c|c|c|}
\hline Instruments & Minimum score & Maximum score & Median score & Mean score & Mean hours of work in 24 hours \\
\hline NAS Mean & 25.30 & 142.9 & 55 & $56.7 \pm 12.5$ & $13.6 \pm 3.0$ \\
\hline NAS Admission & 33.6 & 142.9 & 60.1 & $62.6 \pm 17.3$ & $15.0 \pm 4.2$ \\
\hline NAS Maximum & 33.6 & 142.9 & 65.6 & $67.7 \pm 19.7$ & $16.3 \pm 4.7$ \\
\hline TISS-28 Mean & 7 & 55 & 21 & $22.1 \pm 7.1$ & $11.7 \pm 3.8$ \\
\hline TISS-28 Admission & 10 & 48 & 19 & $20.6 \pm 7.9$ & $10.9 \pm 4.2$ \\
\hline TISS-28 Maximum & 10 & 55 & 22 & $23.7 \pm 9.3$ & $12.6 \pm 5.0$ \\
\hline NEMS Mean & 9 & 51 & 27 & $24.4 \pm 7.7$ & $12.9 \pm 4.1$ \\
\hline NEMS Admission & 9 & 51 & 18 & $23.2 \pm 8.6$ & $12.3 \pm 4.5$ \\
\hline NEMS Maximum & 15 & 51 & 24 & $25.9 \pm 9.8$ & $13.8 \pm 5.2$ \\
\hline
\end{tabular}

NAS = Nursing Activities Score; TISS-28 = Therapeutic Intervention Scoring System-28; NEMS = Nine Equivalents of Nursing Manpower Use Score. 
Table 2 - Mean nursing hours estimated by instruments NAS, TISS-28 and NEMS, divided into Group 1 and Group 2, and the total nursing hours - Porto Alegre, RS, Brazil, from June 2011 to June 2012.

\begin{tabular}{lcccc}
\hline Classification & NAS $^{\S}$ & TISS-28 $^{\S}$ & NEMS $^{\S}$ & $\mathbf{p}^{*}$ \\
\hline Group 1 & $10.2 \pm 2.5^{\mathrm{a}}$ & $5.5 \pm 1.1^{\mathrm{b}}$ & $7.9 \pm 0.2^{\mathrm{c}}$ & $<0.001$ \\
Group 2 & $3.4 \pm 0.9^{\mathrm{a}}$ & $6.3 \pm 3.1^{\mathrm{b}}$ & $5.0 \pm 4.1^{\mathrm{c}}$ & $<0.001$ \\
Total & $13.6 \pm 3.0^{\mathrm{a}}$ & $11.8 \pm 3.8^{\mathrm{b}}$ & $12.9 \pm 4.1^{\mathrm{c}}$ & $<0.001$ \\
\hline
\end{tabular}

NAS $=$ Nursing Activities Score; TISS-28 = Therapeutic Intervention Scoring System-28; NEMS = Nine Equivalents of Nursing Manpower Use Score. SValues expressed as mean and standard deviation. "ANOVA and Tukey's post hoc test, paired evaluation.

a, b, cThe same symbol indicates that no difference was found among the instruments.

Table 3 - Correlations between nursing hours estimated by the instruments NAS, TISS-28 and NEMS and those from Groups 1 and 2 - Porto Alegre, RS, Brazil, from June 2011 to June 2012.

\begin{tabular}{lc}
\hline Correlations & $\mathrm{r}^{*}$ \\
\hline NAS and TISS-28 & 0.716 \\
NAS(1) and TISS-28(1) & 0.536 \\
NAS(2)and TISS-28(2) & 0.807 \\
NAS and NEMS & 0.670 \\
NAS(1) and NEMS(1) & 0.077 \\
NAS(2) and NEMS(2) & 0.787 \\
NEMS and TISS-28 & 0.862 \\
NEMS(1) and TISS-28(1) & 0.138 \\
NEMS(2) and TISS-28(2) & 0.888 \\
\hline
\end{tabular}

NAS = Nursing Activities Score TISS-28 = Therapeutic Intervention Scoring System-28; NEMS = Nine Equivalents of Nursing Manpower Use Score. $p<0.01$ for all the observations. "Pearson's correlation coefficient.

Figure 1 presents the scatter and agreement graphs of the instruments in pairs. In the Bland \& Altman agreement graphs, the mean differences between NAS and TISS-28 were $1.88 \pm 2.63$ hours, between NAS and NEMS were $0.65 \pm 3.05$ hours, and between TISS-28 and NEMS were $-1.23 \pm 2.09$ hours.

Peer agreement in Group 1 and Group 2 of the instruments is shown in Figure 2. The mean difference between NAS(1) and TISS-28(1) was $4.73 \pm 2.12$ hours; NAS(2) and TISS-28(2) was $-2.85 \pm 2.44$ hours; NAS(1) and NEMS(1) was $2.24 \pm 2.48$ hours. In group 2, the mean difference between NAS(2) and NEMS(2) was $-1.59 \pm 3.42$ hours, TISS-28(1) and NEMS(1) was $-2.49 \pm 1$ hours and between TISS-28(2) and NEMS(2) was $1.26 \pm 1.94$ hours. Analyzing the Bland-Altman plots for the groups separately, it was noted that the instruments presenting better agreement were TISS-28(1) and NEMS(1) and TISS-28(2) and NEMS(2).

\section{DISCUSSION}

In this study, we verified the nursing workload, correlation and agreement of the instruments NAS, TISS-28, and NEMS in pediatric patients admitted to a PICU. Our data showed that NAS was the best in evaluating nursing workload. By grouping the items that make up the instruments, separating the category of basic activities from other categories, we can see mainly the differences among the instruments.

When evaluating nursing scores and working hours estimated by the instruments, it was observed that NAS revealed statistically higher scores and nursing working hours when compared to TISS-28 and NEMS. In another study using NAS in pediatric intensive care, the admission $(59.0 \pm 12.0)$, mean $(56.0 \pm 11.0)$ and maximum $(63.0 \pm 15.0)$ values were lower than the findings of the present study. However,TISS-28 values for admission $(33.0 \pm 12.0)$, mean $(29.0 \pm 10.0)$ and maximum $(34.0 \pm 13.0)$ were higher ${ }^{(13)}$. In a Spanish study that sought to evaluate workload with NEMS and NAS in adult intensive care, the mean scores of NAS and NEMS were 66.28 and 26.25 points $^{(21)}$, respectively, which were higher than the means found in the present study. In another Brazilian study conducted in two adult intensive care units that analyzed and compared the correlation between the TISS-28 and NEMS, the mean values for admission were $19.16 \pm 8.79$ and $22.48 \pm 10.03^{(22)}$, respectively, which were lower than in the present study, but NEMS values for admission were higher than those of TISS-28, which is in accordance with our findings. The comparison of raw scores was avoided because the interpretations of the scores are different among the instruments, and that is why the scores were transformed into working hours.

Many studies in adult intensive care units have found higher scores for NAS when compared with TISS-28 and NEMS, and concluded that NAS was the best instrument to measure nursing workload in an intensive care unit ${ }^{(7,21,23-24)}$. In contrast, in another study conducted in a PICU,TISS-28 was higher than NAS, which the authors attempted to explain due to the risk of possible overestimation of NAS in the basic activities category and the tendency of TISS-28 to be higher in the other categories ${ }^{(13)}$. Considering this contradiction in research results, comparing those studies conducted in adult intensive care with pediatric intensive care, and also trying to verify if there is a difference in estimated nursing workload when the intervention categories making up the instruments are evaluated separately, the decision was taken to divide the instruments into two groups: Group 1, formed of items making up the basic activities category; Group 2, comprising items belonging to the other support and therapeutic intervention categories. When analyzing the mean hours of work divided into Group 1 and Group 2, and the mean total hours of NAS, TISS-28 and NEMS, it is noted that in Group 1 NAS is distinctive in the assessment of nursing workload. However, TISS-28 was the instrument that best measured the hours spent by the nursing staff in Group 2, as it presented the best workload estimation, which is statistically significant when compared to the other instruments, as well as being the most meticulous regarding the verification of workload in those activities. A relevant finding of the present research is TISS-28 as being the instrument with less variation 


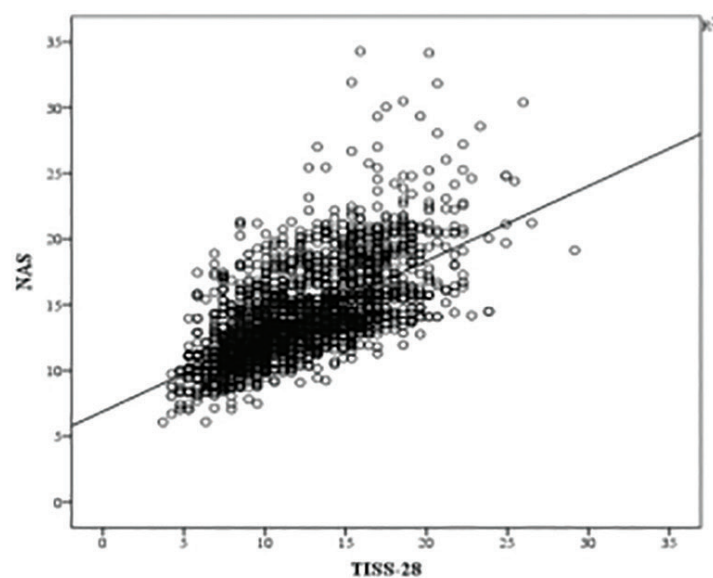

Figure 1A

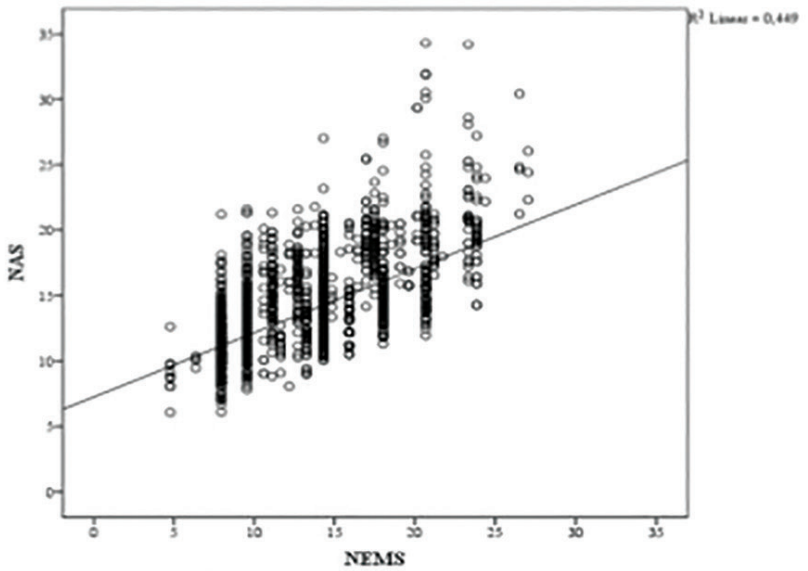

Figure 1C

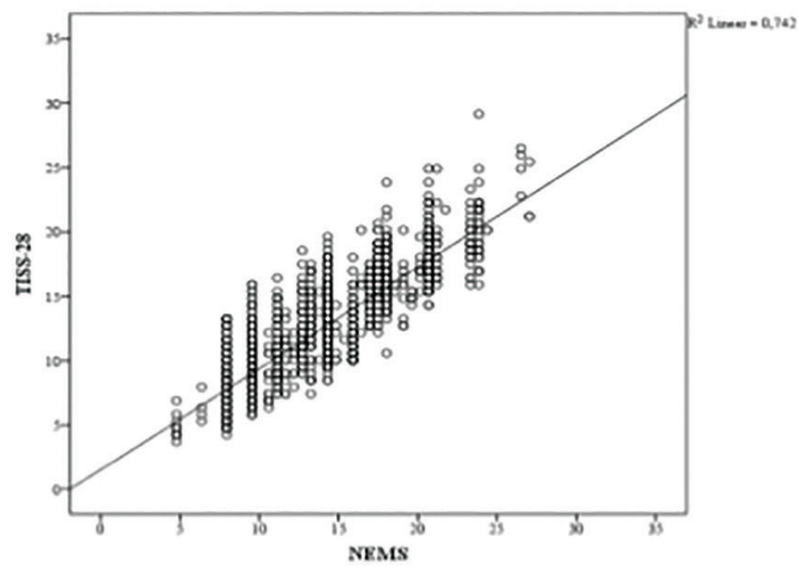

Figure 1E

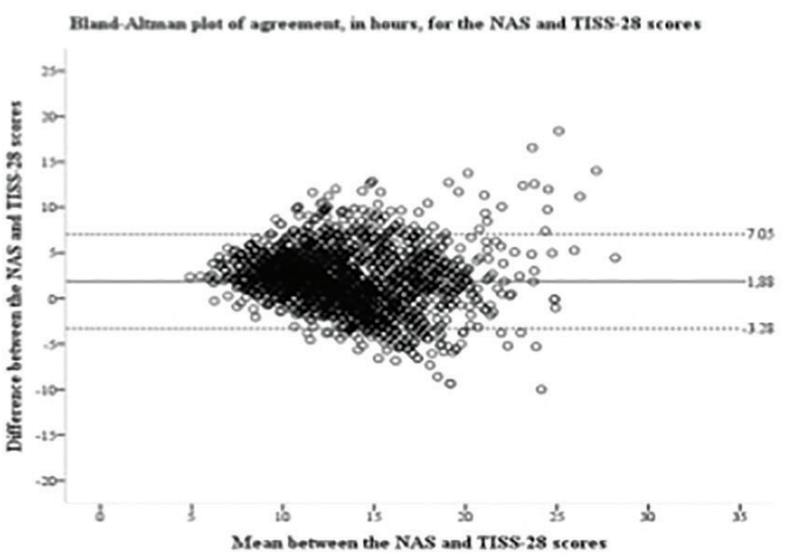

Figure lB

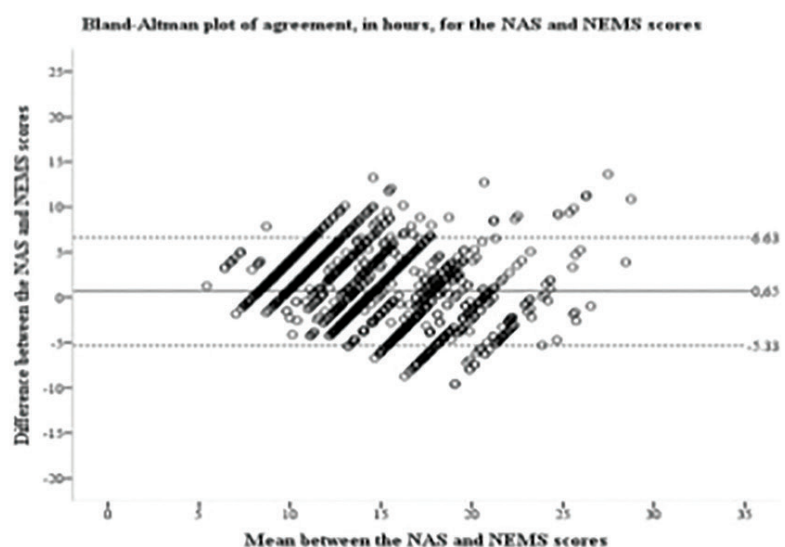

Figure 1D

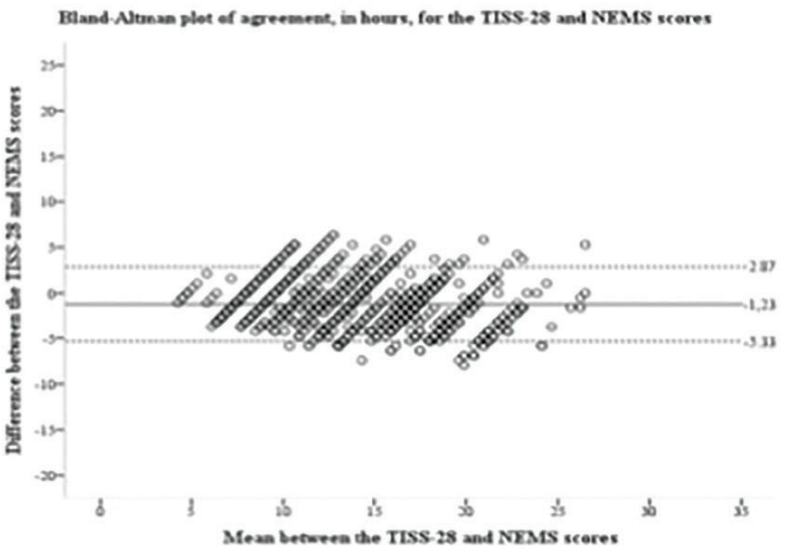

Figure $1 \mathrm{~F}$

Figure 1 - Scatter and agreement graphs of the instruments in pairs.

A: Scatter graph for the Nursing Activities Score (NAS) and Therapeutic Intervention Scoring System-28 (TISS-28); B: Agreement between the NAS and TISS-28 instruments; C: Dispersion plot for NAS and Nine Equivalents of Nursing Manpower use Score (NEMS); D: Agreement between instruments NAS and NEMS; E: Dispersion plot for the TISS-28 and NEMS; F: Agreement between instruments TISS-28 and NEMS.

when Groups 1 and 2 were compared. The instrument NAS in Group 1 was clearly superior in the evaluation of basic activities, while also being the one that least evaluated the other categories of care and intervention, when compared to other instruments, which corroborates the explanation given by the study previously cited. Nevertheless, the total
NAS score in the present study was higher when compared to the other instruments, confirming the finding of adult intensive care studies ${ }^{(7,21,23-24)}$

The instruments NAS and TISS-28 presented a strong correlation in our study, but it was observed that with the increase in nursing workload, there was a decrease in 


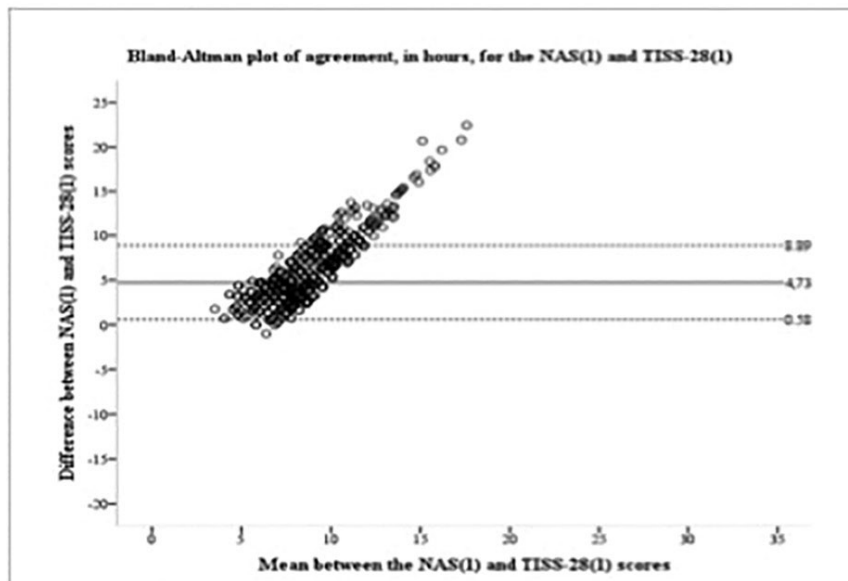

Figure 2A

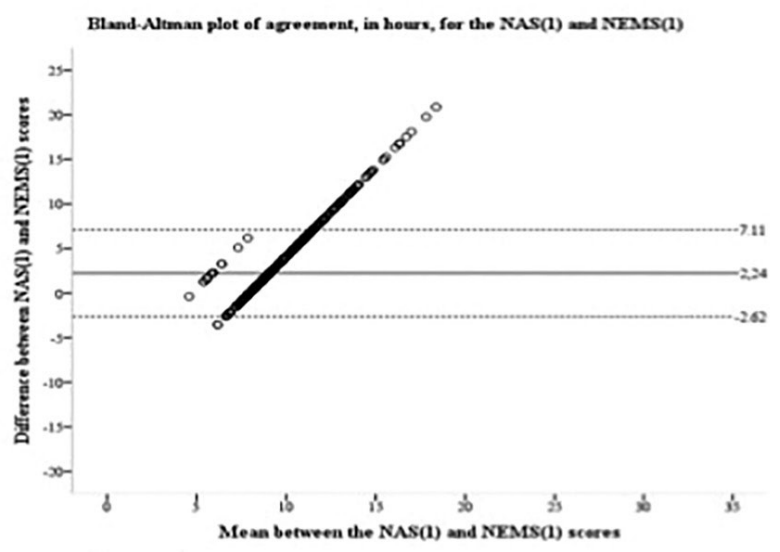

Figure 2C

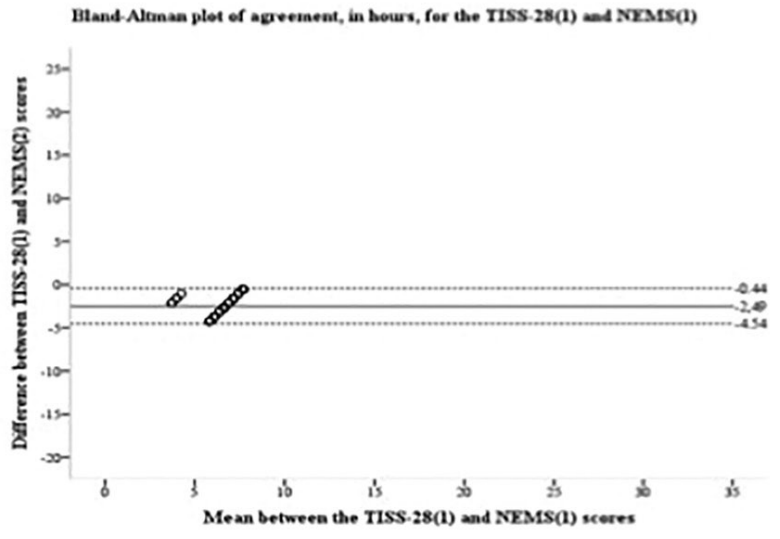

Figure 2E

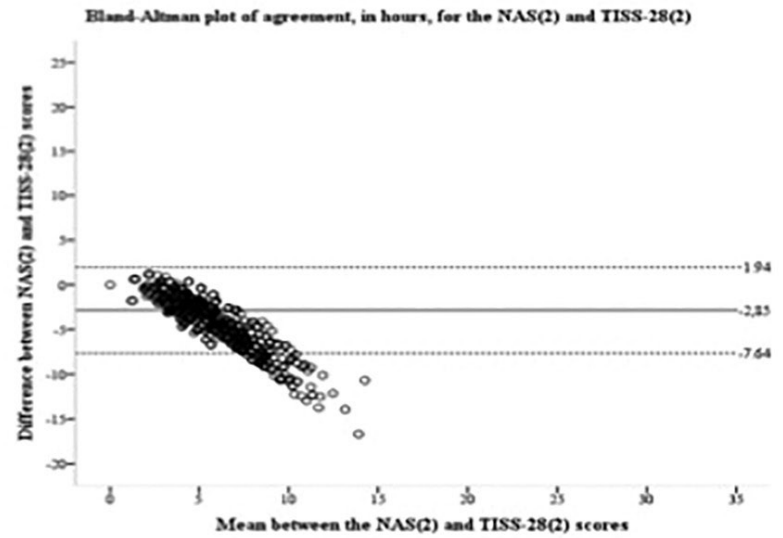

Figure 2B

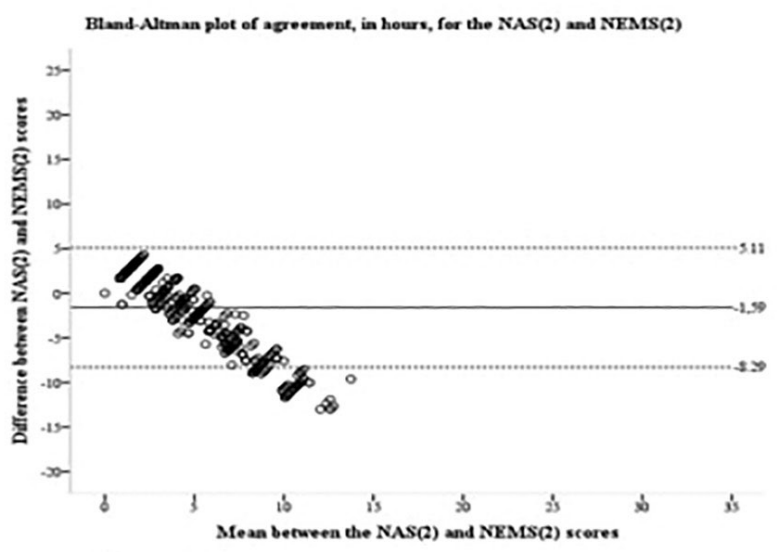

Figure 2D

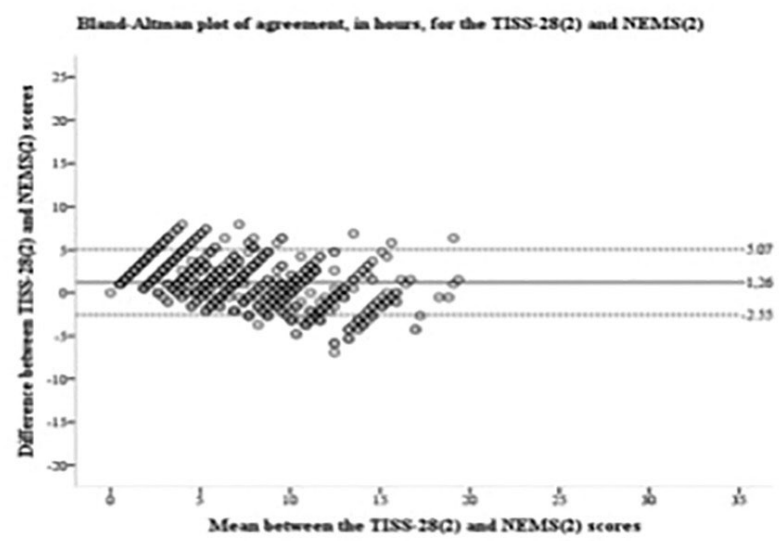

Figure $2 \mathrm{~F}$

Figure 2 - Peer agreement in Group 1 and Group 2 of the instruments.

Presentation of the agreements between the instruments: NAS(1) and TISS-28(1) (A); NAS(2) and TISS-28(2) (B); NAS(1) and NEMS(1) (C); NAS(2) and NEMS(2) (D); TISS-28(1) and NEMS(1) (E); and TISS-28(2) and NEMS(2) (F).

agreement between the two instruments, and the hours of work estimated by NAS were higher than those estimated by TISS-28. This can be explained by the analysis of the source of data collection, as the data collected for TISS-28 are more generic, mainly in the basic activities category, while data from NAS are much more specific in this category (due to a higher number of items evaluated and the presence of sub-items with different scores), which allows the increase or decrease of working hours and gives greater capacity to detect these variations. Other studies have found moderate correlations $^{(6,7,73)}$ between NAS and TISS-28, but good agreement between these instruments ${ }^{(13)}$. 
The instruments NAS and NEMS presented a moderate correlation. A cross-sectional study analyzing nursing workload in an adult intensive care unit also found a moderate Pearson correlation $(r=0.62)$ between NAS and $\mathrm{NEMS}^{(23)}$. Another study evaluating the Spanish version of NAS obtained a Spearman correlation of 0.70 $\left(\mathrm{R}^{2}=0.5126\right)$ between the two tools ${ }^{(5)}$. In a Norwegian study using NEMS and NAS, performed in four intensive care units, the Spearman correlation between the scores varied between 0.16 and 0.40 , being considered as weak significant correlations $^{(24)}$. Weak correlations have also been identified in another Spanish study ${ }^{(25)}$. A possible explanation for this is that NEMS is an instrument evaluating fewer items and, therefore, can be considered "poor" and with less power of discrimination when compared to NAS. Nevertheless, when the agreement between the instruments was evaluated, NAS and NEMS were those that presented the smallest difference between the estimated working hours.

The instruments TISS-28 and NEMS showed good correlation and agreement in our study, and this result was already found in another study carried out in the same hospital unit ${ }^{(26)}$. It can be inferred that the basis of this result lies in the fact that the latter instrument is derived from the former, and though NEMS evaluates only nine items, a score adjustment was performed to compensate for this and maintain balance for the total workload between TISS-28 and NEMS. Having said that, it is important to note that even though NEMS evaluates few therapeutic interventions, it is able to estimate working hours closer to those recommended in Brazil, as well as being statistically superior when compared to TISS-28.

Through separate evaluations of the instruments in Groups 1 and 2, weak and moderate correlations in Group 1 (basic activities) and strong correlations in the paired evaluations in Group 2 (therapeutic interventions) were found. This infers and even confirms that an important change in these instruments occurred in the basic activities category.

The best agreement found between TISS-28(1) and NEMS(1), and TISS-28(2) and NEMS(2), was when groups were evaluated. This confirmed that TISS-28 and NEMS presented the best agreement in the pairs evaluation, both when considering the values of estimated total hours and when evaluating the two groups separately. The mean total nursing hours found by NAS, TISS-28 and NEMS showed a higher workload measured by NAS. Based on data analysis, it is possible to state that NAS stood out and also estimates the hours closer to those advocated by the Brazilian Federal Nursing Council, therefore being the best instrument to use in the sizing of nursing staff numbers in the hospital unit where the study was conducted.

Although there is a time gap between the time of data collection and of data analysis, we believe that this does not diminish the strength of our results that were collected prospectively and for a period of one year. Through 4617 observations, we demonstrate the various nuances and profiles of patients hospitalized in the PICU during this period, which interferes with the measurement of the nursing workload. In addition, in this period, no studies in PICU that would invalidate our findings were published. We believe that as the hospitalized children were accompanied during the whole period of their stay in the unit and as the study was conducted over a prolonged time, it was possible to obtain a real mean evaluation of workload, which is close to that of other hospital units presenting similar structure and health characteristics. Our study has some limitations as the nursing time required for one of the NAS items could at some moment have been recorded incorrectly, either unconsciously or through misinterpretation on the part of the nurse responsible, allocating more time for a task than was spent. Nonetheless, an attempt was made to minimize this bias by having the data collection of items considered more critical at the end of each work shift.

\section{CONCLUSION}

The NAS instrument was the best instrument for workload evaluation, estimating total average working hours closer to the recommended for nursing in these units. The data found in the stratifications indicated that NAS stood out in the estimation of average hours in basic nursing care activities. In the analysis of the most specialized tasks, NAS showed a strong correlation with TISS-28 and NEMS, even with lower estimates of working hours.

\section{RESUMO}

Objetivo: Comparar a carga de trabalho de enfermagem por meio dos instrumentos Nursing Activities Score (NAS), Therapeutic Intervention Scoring System-28 (TISS-28) e Nine Equivalents of Nursing Manpower Use Score (NEMS) em crianças internadas em Unidade de Terapia Intensiva Pediátrica de um hospital universitário. Método: Estudo de coorte prospectivo realizado em Unidade de Terapia Intensiva Pediátrica, com amostra constituída por todas as crianças internadas durante o período do estudo. A carga de trabalho de enfermagem foi avaliada por meio dos instrumentos TISS-28, NEMS e NAS, e posteriormente dividida em dois grupos: Grupo 1 formando uma categoria de itens de atividades básicas; Grupo 2 formando uma categoria de outras atividades de apoio e intervenção. Resultados: A amostra foi composta por 490 internações em Unidade de Terapia Intensiva Pediátrica, totalizando 4617 observações. O NAS apresentou a melhor estimativa do total de horas de trabalho. O TISS-28 e o NEMS apresentaram melhor concordância e os resultados apresentaram fortes correlações entre NAS e TISS-28 e entre NEMS e TISS-28. No Grupo 1 (atividades básicas), o NAS(1) e o TISS-28(1) apresentaram correlação moderada, no Grupo 2 (atividades especializadas) os três instrumentos apresentaram correlações fortes. Conclusão: O NAS destacou-se na avaliação da carga de trabalho de enfermagem e apresentou boa correlação e concordância com o TISS-28.

\section{DESCRITORES}

Enfermagem Pediátrica; Carga de Trabalho; Unidades de Terapia Intensiva Pediátrica; Equipe de Enfermagem. 


\section{RESUMEN}

Objetivo: Comparar la carga de trabajo de enfermería a través de los instrumentos Nursing Activities Score (NAS), Therapeutic Intervention Scoring System-28 (TISS-28) y Nine Equivalents of Nursing Manpower Use Score (NEMS) en niños ingresados en Unidad de Cuidados Intensivos Pediátrica de un hospital universitario. Método: Estudio de cohorte prospectivo realizado en Unidad de Cuidados Intensivos Pediátrica, con muestra constituida por todos los niños ingresados durante el período de estudio. La carga de trabajo de enfermería fue evaluada a través de los instrumentos TISS-28, NEMS y NAS y, posteriormente dividida en dos grupos: Grupo 1 formando una categoría de ítems de actividades básicas; Grupo 2 formando una categoría de otras actividades de apoyo e intervención. Resultados: La muestra fue compuesta por 490 ingresos en Unidad de Cuidados Intensivos Pediátrica, en un total de 4617 observaciones. El NAS presentó la mejor estimativa del total de horas trabajadas. E1 TISS-28 y el NEMS presentaron mejor concordancia y los resultados demostraron fuertes correlaciones entre NAS y TISS-28 y entre NEMS y TISS-28. En el grupo 1 (actividades básicas), el NAS(1) y el TISS-28(1) presentaron correlación moderada, en el Grupo 2 (actividades especializadas) los tres instrumentos presentaron correlaciones fuertes. Consideraciones Finales: E1 NAS se destacó en la evaluación de la carga de trabajo de enfermería y presentó buena correlación y concordancia con el TISS-28.

\section{DESCRIPTORES}

Enfermería Pediátrica; Carga de Trabajo; Unidades de Cuidado Intensivo Pediátrico; Grupo de Enfermería.

\section{REFERENCES}

1. Perroca MG, Jericó MC, Calil ÂSG. Composition of the nursing staff in Intensive Care Units. Acta Paul Enferm. 2011;24(2):1990205. https:// doi.org/10.1590/S0103-21002011000200007

2. Miranda DR, Rijk A, Schaufeli W. Simplified Therapeutic Intervention Scoring System: the TISS-28 items - results from a multicenter study. Crit Care Med. 1996;24(1):64-73. http://dx.doi.org/10.1097/00003246-199601000-00012

3. Reis Miranda D, Moreno R, lapichino G. Nine Equivalents of Nursing Manpower use Score (NEMS). Intensive Care Med. 1997;23(7): 760-5. http://dx.doi.org/10.1007/s001340050406.

4. Miranda DR, Nap R, Rijk A, Schaufeli W, lapichino G; TISS Working Group. Therapeutic Intervention Scoring System: nursing activities score. Crit Care Med. 2003;31(2):374-82. http://dx.doi.org/10.1097/01.CCM.0000045567.78801.CC.

5. Sánchez-Sánchez MM, Arias-Rivera S, Fraile-Gamo MP, Thuissard-Vasallo IJ, Frutos-Vivar F. Validating the Spanish version of the Nursing Activities Score. Enferm Intensiva. 2015;26(2):63-71. http://d.xdoi.org/0.1016/j.enfi.2015.02.003.

6. Queijo AF, Padilha KG. Nursing Activities Score (NAS): cross-cultural adaptation and validation to Portuguese language. Rev Esc Enferm USP. 2009;43(spe):1018-25. http://dx.doi.org/10.1590/S0080-62342009000500004

7. Altafin JAM, Grion CMC, Tanita MT, Festti J, Cardoso LTQ, Veiga CFF, et al. Nursing Activities Score and workload in the intensive care unit of a university hospital. Rev Bras Ter Intensiva. 2014;26(3):292-8. http://dx.doi.org/10.5935/0103-507x.20140041.

8. Griffiths P, Saville C, Ball J. Nursing workload, nurse staffing methodologies and tools: a systematic scoping review and discussion. Int J Nurs Stud. 2020;103:103487. https://doi.org/10.1016/j.ijnurstu.2019.103487

9. Hoogendoorn ME, Margadant CC, Brinkman S. Workload scoring systems in the Intensive Care and their ability to quantify the need for nursing time: a systematic literature review. Int J Nurs Stud. 2020;101:103408. http://dx.doi.org/10.1016/j.ijnurstu.2019.103408

10. Lucchini A, De Felippis C, Elli S, Schifano L, Rolla F, Pegoraro F, et al. Nursing Activities Score (NAS): 5 years of experience in the intensive care units of an Italian University hospital. Intensive Crit Care Nurs. 2014;30(3):152-8. http://dx.doi.org/10.1016/j.iccn.2013.10.004.

11. Nogueira LS, Koike KM, Sardinha DS, Padilha KG, Sousa RMC. Nursing workload in public and private intensive care units. Rev Bras Ter Intensiva. 2013;25(3):225-32. http://dx.doi.org/10.5935/0103-507X.20130039

12. Padilha KG, Sousa RMC, Kimura M, Miyadahira AMK, Cruz DALM, Vattimo MF, et al. Nursing workload in intensive care units: a study using the Therapeutic Intervention Scoring System-28 (TISS-28). Intensive Crit Care Nurs. 2007;23(3):162-9. http://dx.doi.org/10.1016/j. iccn.2006.07.004

13. Campagner AOM, Garcia PCR, Piva JP. Aplicação de escores para estimar carga de trabalho de enfermagem em unidade de terapia intensive pediátrica. Rev Bras Ter Intensiva 2014;26(1):36-43. http://dx.doi.org/10.5935/0103-507x.20140006

14. Monroy JC, Hurtado Pardos B. Utilization of the nine equivalents of nursing manpower use score (NEMS) in a pediatric intensive care unit. Enferm Intensiva. 2002;13(3):107-12. http://dx.doi.org/10.1016/s1130-2399(02)78071-1

15. Canabarro ST, Bandeira MP, Stochero Velozo KD, Eidt OR, Piva JP, Ramos Garcia PC. Therapeutic intervention scoring system application in a pediatric intensive care unit. Ciênc Saúde. 2010;2(2):96. http://dx.doi.org/10.15448/1983-652X.2009.2.6247

16. Padilha KG, Sousa RMC, Miyadahira AMK, Cruz DALM, Vattimo MFF, Kimura M, et al. Therapeutic intervention scoring system-28 (TISS-28): diretrizes para aplicação. Rev Esc Enferm USP. 2005;39(2):229-33. http://dx.doi.org/10.1590/S0080-62342005000200014

17. Canabarro ST, Velozo KDS, Eidt OR, Piva JP, Garcia PCR. Nine Equivalents of Nursing Manpower Use Score (NEMS): a study of its historical process. Rev Gaúcha Enferm. 2010;31(3):584-90. http://dx.doi.org/10.1590/S1983-14472010000300025

18. Ducci AJ, Zanei SSV, Whitaker IY. Nursing workload to verify nurse/patient ratio in a cardiology ICU. Rev Esc Enferm USP. 2008;42(4): 673-80. http://dx.doi.org/10.1590/s0080-62342008000400009

19. Castro MCN, Dell'Acqua MCQ, Corrente JE, Zornoff DCM, Arantes LF. Aplicativo informatizado com o nursing activities score: instrumento para gerenciamento da assistência em unidade de terapia intensiva. Texto Contexto Enferm. 2009;18(3):577-85. http://dx.doi.org/10.1590/ S0104-07072009000300022.

20. Bland JM, Altman DG. Statistical methods for assessing agreement between two methods of clinical measurement. Lancet. 1986;1(8476):307-10. 
21. Carmona-Monge FJ, Rollán Rodríguez GM, Quirós Herranz C, García Gómez S, Marín-Morales D. Evaluation of the nursing workload through the Nine Equivalents for Nursing Manpower Use Scale and the Nursing Activities Score: a prospective correlation study. Intensive Crit Care Nurs. 2013;29(4):228-33. http://dx.doi.org/10.1016/j.iccn.2013.03.003

22. Souza Urbanetto J, Travi Canabarro S, Prado Lima Figueiredo AE, Weber G, Pereira dos Santos R, Stein K, et al. Correlation between the TISS-28 and NEMS indicators in an intensive care unit. Int J Nurs Pract. 2014;20(4):375-81. http://dx.doi.org/10.1111/ijn.12183.

23. Valls-Matarín J, Salamero-Amorós M, Roldán-Gil C. Análisis de la carga de trabajo y uso de los recursos enfermeros en una unidad de cuidados intensivos. Enferm Intensiva. 2015;26(2):72-81. http://dx.doi.org/10.1016/j.enfi.2015.02.002

24. Stafsetha SK, Solms D, Bredal IS. The characterisation of workloads and nursing staff allocation in intensive care units: a descriptive study using the Nursing Activities Score for the first time in Norway. Intensive Crit Care Nurs. 2011;27(5):290-4. http://dx.doi.org/10.1016/j. iccn.2011.07.003

25. Bernat Adell A, Abizanda Campos R, Yvars Bou M, Quintana Bellmunt J, Gascó García C, Soriano Canuto M, et al. Care work load in critical patients: comparative study NEMS versus NAS. Enferm Intensiva. 2006;17(2):67-77. http://dx.doi.org/10.1016/s1130-2399(06)73918-9

26. Canabarro ST, Velozo KDS, Eidt OR, Piva JP, Garcia PCR. Validação Concorrente de Escores de Enfermagem (NEMS e TISS-28) em terapia intensiva pediátrica. Acta Paul Enferm. 2013;26(2):123-9. http://dx.doi.org/10.1590/S0103-21002013000200004 